\title{
Iparági sérülékenység a pandémia tükrében
}

\author{
Hauck Zsuzsanna, Vasvári Tamás*, Vörös József \\ Pécsi Tudományegyetem Közgazdaságtudományi Kar, Pécs, Magyarország \\ Beérkezett: 2021. augusztus 9.; Elfogadva: 2021. szeptember 9.
}

\begin{abstract}
Összefoglalás
Jelen tanulmányban a termelési folyamatokat, valamint statisztikai adatokat elemezve azt vizsgáljuk, hogy a pandémia során milyen hatások érték az inputokat, magát a termelést, az outputokat, illetve hogyan változtak meg olyan versenyprioritási tényezők, mint az idő, a minőség vagy a rugalmasság. Mivel a rövidebb, a kevésbé komplex és rugalmasabb értékláncok válságállóbbnak túnnek, ez felgyorsíthatja az ellátási láncok regionalizációját, amit tovább fokoz, hogy a termelőszektor gyors visszarendeződésével szemben a szolgáltató ágazatoknak elhúzódó kilábalással kell szembenézniük. Ezért azt is megvizsgáltuk, hogy az egyes országok ellenálló képessége függ-e a termeló szektor méretétől. Eredményeink alapján, ahol nagyobb az ipar aránya, ott gyorsabban képes a gazdaság talpra állni, ami újabb lökést adhat a fejlett államok iparfejlesztési törekvéseinek.
\end{abstract}

Kulcsszavak: ellátási láncok, sérülékenység, rugalmasság, termelés, COVID-19

\section{Industrial vulnerability in the light of the COVID-19 pandemic}

\author{
Zsuzsanna Hauck, Tamás Vasvári, József Vörös \\ University of Pécs Faculty of Business and Economics, Pécs, Hungary
}

\begin{abstract}
The coronavirus epidemic posed challenges to all. However, with proper discipline, increased efficiency and adaptability, companies and economies can emerge stronger from this situation. In this study, we examine vulnerability of industries along three dimensions according to the general model of production complemented by aggregate statistics from Eurostat.

In terms of procurement, shorter value chains seem more resilient than complex and long supply chains. Supplier risks may be also mitigated by increasing the number of suppliers of critical inputs. The costs and risks of transporting goods are also increasing. 90\% of industrial products are involved in international trade, mostly transported through maritime shipping that faces significant increase in tariffs, and the difficulty of replacing crews could lead to further disruptions to the operation of maritime routes. Thus, it is not surprising that the pandemic has increased the issue of supply chain flexibility and simplification, and has drawn attention to the importance of inventories and input replacement. Companies may consider to diversify production sites or even reshore or nearshore their production.

The rate of recovery varies in each sector: in services requiring a personal presence, such as tourism, the sudden economic downturn is followed by a slow growth, contrary to the rapid rebound of industrial production. Therefore, countries with significant manufacturing will witness $\mathrm{V}$-shaped recovery, while higher reliance on services is characterized by slower and longer L-shaped scenario. Thus, the pandemic also pointed out that industrial production is key in a national economy: besides that industrial innovations increase productivity (and living standards) and manufacturing functions also have a significant multiplier effect on the service sector, manufacturing also has significant resistance against a pandemic. This could give a further push to the ongoing industrial development programs of developed economies such as Germany, the United States, or the European Union. At the same time, services that are able to move online show no decline, while service requiring a personal presence may struggle in the long run. Overall, structural changes are inevitable and companies have to adapt to the novel consuming and working preferences.
\end{abstract}

Keywords: supply chain, resilience, vulnerability, manufacturing, COVID-19 


\section{Bevezetés}

Mint minden válságos szituáció, a koronavírus-járvány is kihívás elé állította a gazdasági szereplőket. Azonban megfelelő fegyelmezettséggel, a hatékonyság és az alkalmazkodóképesség növelésével a vállalatok és gazdaságok megerősödve is kikerülhetnek ebből a helyzetből (Reeves et al. 2020). Egyelöre azonban bizonytalan, hogy meddig és milyen mértékben kell alkalmazkodni e változó körülményekhez. Míg a korábbi járványok okozta gazdasági sokkok után gyors visszarendeződés történt (Carlsson-Szlezak-Reeves-Swartz 2020), ez korántsem tûnik egyértelmúnek a koronavírus esetében. Egyrészt a hirtelen megváltozott fogyasztói igények, a keresleti sokkok számos esetben tartósnak bizonyulhatnak (pl. ételházhozszállítás, otthoni szórakoztatás, távmunka). Másrészt a kínálati oldalon középtávon is érezhetôek maradnak az ellátási láncokat ért sérülések: annak ellenére például, hogy az autóipar viszonylag gyorsan vissza tudott állni a korábbi kibocsátási szintre, az Audi magyarországi gyárai még 2021 júniusában is egyhetes leállásra kényszerültek a félvezető́ket tartalmazó alkatrészek hiánya miatt (Csatári 2021; Nagy 2021).

A kilábalás mértéke szektoronként is eltérő: a személyes jelenlétet igénylő szolgáltatások területén, mint például a turizmus, a hirtelen gazdasági visszaesést lassú kilábalás jellemzi (pl. de Vet et al. 2021), szemben az ipari termelés gyors visszarendeződésével. Az árupiacot azonban a szállítási költségek növekedése is sújtja. Köszönhetően annak, hogy az elmúlt harminc évben a gyártási tevékenység - mint legalacsonyabb hozzáadott értékkel bíró vállalati funkció - fokozatosan tevődött át a fejlett országokból a Távol-Keletre, mára az ipartermékek csaknem 90\%-a részt vesz a nemzetközi kereskedelemben; ennek túlnyomó részét lebonyolító nemzetközi hajózásban pedig jelentős növekedést mutatnak a tarifák, ráadásul a legénység felváltásának nehézségei további fennakadásokat hozhatnak a tengeri útvonalak üzemeltetésében. Ennek következtében nem meglepő, hogy a koronavírus-járvány hatására felértékelődött az ellátási láncok rugalmasságának és egyszerúsítésének kérdése: újra kell gondolni a helyettesítési és készletezési lehetőségeket, és lehetőség szerint olyan gyártási technológiákat kell alkalmazni, amelyek növelik a flexibilitást és adott esetben csökkenthetik a személyes kontaktusok számát is (Shỉ, 2020). A pandémia hatására ezért várhatóan több vállalat fog a távol-keleti termelési helyszínek diverzifikálása (Sheffi 2020) vagy akár a termelés anyaországba vagy közelebbi régiókba való visszatelepítése mellett dönteni (Hauck-Longaner-Vasvári 2021). Utóbbinak ráadásul az ellátási láncok jelentette kockázatok csökkentésén túl pozitív hatása lehet a fejlett országok innovációs képességére, a szolgáltató ágazatokra, de - mint azt később bemutatjuk - a nagyobb ipari részaránnyal bíró országok a járvány okozta külső gazdasági sokkokkal szemben is ellenállóbbnak bizonyulhatnak.
A továbbiakban az ellátási láncokat és a termelést érintôen mutatjuk be a pandémia néhány fontosabb következményét. Nem vállalkozunk az elmúlt másfél év könyvtárnyira duzzadt szakirodalmának átfogó bemutatására. Ezzel szemben termelési/szolgáltatási folyamatok alapján, makroszintű statisztikák segítségével mutatunk rá az eltérő iparági hatásokra. Mivel minden termelési folyamat általánosan leírható a szükséges (1) inputok, az azokat (2) transzformáló tevékenységek, valamint az ezek eredményeként létrejövő (3) outputok segítségével (Heizer et al. 2017; Vörös 2018), ezért ennek a struktúrának megfelelően építettük fel tanulmányunkat. Először a beszerzés, majd a közvetlen termelés, végül a végtermékek elosztásának aspektusait mutatjuk be. Tanulmányunk zárásaként pedig levonjuk a fơbb tanulságokat.

\section{A pandémia fóbb hatásai az inputok beszerzésére}

A pandémia rávilágított, hogy a folyamat eleje, azaz az inputok beszerzésének körülményei (költsége, ideje) mekkora hatással van nemcsak egy-egy vállalat, de a globális ellátási láncok múködésére is. Az egészségügyi okokból lezárt határok lassították, gyakran meg is hiúsították a beszállítóktól érkező nyersanyagok, félkész termékek beérkezését. Mivel a kiváló minőségre és hatékony termelésre törekvő gyárak többsége Just-in-Time rendszerben ${ }^{1}$ termel, biztonsági készletei nem számolnak nagymértékú inputkieséssel, ezért a beszállítások kimaradása már rövid távon is megbéníthatja a termelést. A beszerzést a szállítási problémákon túl egy-egy beszállító termelésének visszaesése, a szerződöttnél alacsonyabb szállítási volumen is akadályozhatja. Az autóiparban az utóbbi hónapokban megfigyelhetó chiphiány jó példa arra, hogy egy-egy alkatrész hiánya képes a teljes termelés megbénítására is. Ez esetben a globális hiány alapvetố oka, hogy a gyártók a koronavírus miatt jelentős kereslet-visszaeséssel számoltak, ezért kevesebb chipet rendeltek beszállítóiktól. A chipek gyártói az elektronikai ipar növekvő keresletének kielégítésére kezdtek koncentrálni, ami azóta nemcsak az autóiparban, de számos további iparágban chiphiány kialakulásához, így gyártási problémákhoz vezetett (Render 2021a, 2021b). Ilyen esetben jelenthet megoldást az inputok helyettesítése, illetve egyes alkatrészek más beszállítótól való beszerzése. Ennek során azonban valamely versenyprioritási tényező jellemzően háttérbe szorul, így az elérhetőség „ára” a költségek növekedése, a minőség (kiválóság, konzisztencia) romlása, a lassabb teljesítés (kisebb megbízhatóság) vagy az alacsonyabb flexibilitás (testre sza-

\footnotetext{
A Just-in-Time (éppen időben) termelésirányítási filozófia arra összpontosít, hogy a termelési-szolgáltatási rendszerekben levő készletek a lehető legkisebbek legyenek. Azt az elvet igyekszik ugyanis tökéletesen megvalósítani, hogy mindenből csak az és csak annyi legyen jelen a termelési folyamatban, amennyire éppen szükség van, és ott, ahol éppen kell (Vörös 2018).
} 
110

100



—— Lari termelés _ _- Félkész termék importárak —_Eélkész termékek importja EU-n belülröl ....... Félkész termékek importja EU-n kívülről

1. ábra

$\mid \begin{aligned} & \text { Az ipari tı } \\ & \text { Forrás: Eı }\end{aligned}$

bottság, széles választék, nagy volumen). A versenyprioritási tényezők változása pedig hatással lesz várhatóan a folyamat végén előálló termék/szolgáltatás tulajdonságaira, ezzel együtt pedig az arra irányuló keresletre, illetve fogyasztói elégedettségre. Ezért hosszú távon a beszállítók kiválasztására, a velük való szerződések megkötésére alkalmazott algoritmusok (pl. Szabó-Hauck 2019; Dobos-Vörösmarty 2020) átgondolására, a megszokottnál nagyobb mértékü volatilitás tervezésére van szükség. Ezen felül az üzleti partnerek megválasztásakor a költségmegtakarítás mellett hangsúlyt kell fektetni a megbízhatóságra, valamint a sokkhatásra való reagálási képességekre is (Choi-Rogers-Vakil 2020).

A beszállítók kiválasztását ugyanakkor a távolság ${ }^{2}$ is befolyásolja. A nemzetközi kereskedelem 80 százalékát lebonyolító tengeri hajózás kapcsán pedig az utóbbi időben számos eset rámutatott a tengeri szállítmányozás törékenységére, jelentőségének alulértékeltségére. Az Ever Given konténerszállító hajó 2021 márciusának végén keresztbefordult a világkereskedelem 12 százalékát lebonyolító Szuezi-csatornában, amelyen csaknem négyszáz további hajó várt az áthaladásra. A fennakadás ugyan csak hat napig tartott, de a kikötőknél való fel- és lerakodás torlódása miatt a baleset hónapokig hatással lehet a szállítási határidőkre és az árakra. Utóbbiak egyébként is emelkedőben vannak, a konténer és konténerhajók hiánya miatt ugyanis a tengeri konténerszállítási tarifák az elmúlt egy évben több mint megnégyszereződtek (Page 2021; UNCTAD 2021). A problémát tovább fokozza,

\footnotetext{
2 Távolság alatt ez esetben földrajzi távolságot értünk. Ugyanakkor a partnerek között további számos távolság értelmezhető (pl. kulturális, politikai, gazdasági), erről részletesen ír Ghemawat (2001).
}

hogy a konténerszállító hajók legénységét alacsony átoltottságuk és a delta-variáns terjedése miatt nem lehet felváltani (Szabad Európa 2021).

A beszállítói kapcsolatokban bekövetkezett változásokat szemlélteti az 1 . ábra, amely az eurózóna ${ }^{3}$ termelő vállalatai által felhasznált félkész termékek beszerzését és azok árindexét mutatja be 2019 és 2021 első negyedéve között. Az ipari termeléssel párhuzamosan az unión belüli és kívüli beszerzés is jelentősen visszaesett (szinte késedelem nélkül, ami az alacsony raktárkészletre és a Justin-Time termelési rendszerek dominanciájára utalhat), amit az árak enyhébb csökkenése kísért. Azonban a félkész termékek unión belüli beszerzésének visszarendeződése gyorsabb (már 2020 végére elérte a járvány előtti szintet), jobban követi az ipari termelés visszapattanását, ami arra enged következtetni, hogy rövid távon az eurózóna vállalatai más tagállamokból szereztek be olyan termékeket és alkatrészeket, amelyeket korábban az unión kívülről importáltak. Az importárak 2021 elején tapasztalható növekedését a kereslet élénkülése mellett a tengeri szállítási tarifák növekedése okozhatja.

\section{Közvetlenül a termelési/szolgáltatási folyamatra ható tényezők}

Heizer és munkatársai (Heizer-Render-Munson 2017) alapján a termelékenységnövekedés csaknem kétharmada függ az emberi tényezőtől (10 százalékban a munkaerő-

${ }^{3}$ Csak az eurózóna tagállamai kötelezettek az importárakra vonatkozó adatszol gáltatásra, ezért a többi adatot is e 19 államra vonatkozóan tüntettük fel. Azonban elmondható, hogy a trendek az eurózóna és az Európai Unió vonatkozásá ban csaknem teljes egyezőséget mutatnak. 
120
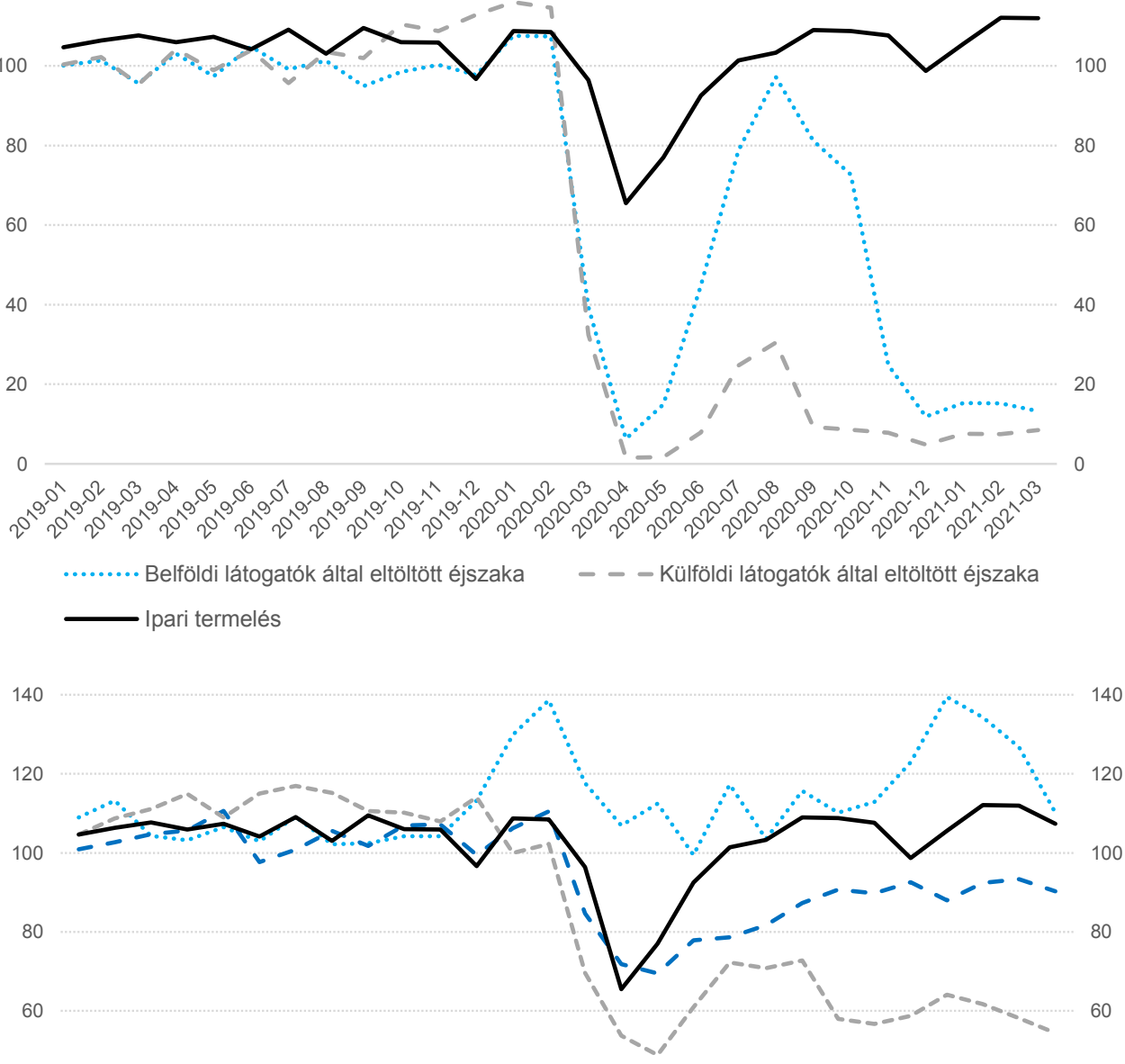

40

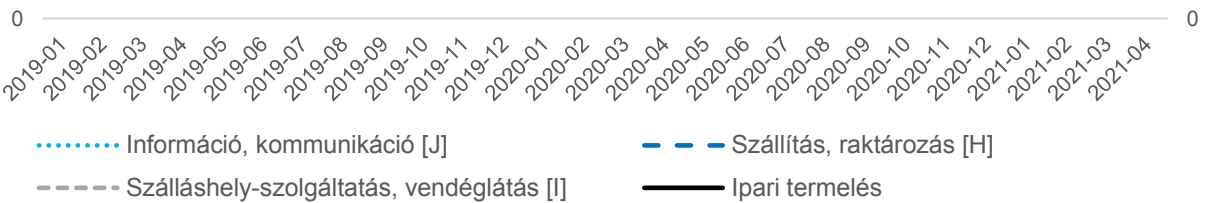

2. ábra

Az ipari termelés és egyes szolgáltató ágazatok kibocsátásának alakulása Magyarországon (százalék, hónap/hónap, bázis = 2018)
Forrás: Eurostat adatok alapján saját számítás és szerkesztés

től, 52 százalékban a menedzsmenttől), ezért egy járvány eredetû́ válság jelentős hatással lehet a vállalatok múködésére. Az egyes iparágakat azonban eltérő módon befolyásolja a fizikai kontaktusok számának csökkentése, más-más eszközök állnak a vezetés rendelkezésére a problémák áthidalására, ezért a válság lefutása is különböző lehet.

$\mathrm{Az}$ egészségügyi eljárásrendek bevezetése (pl. kevesebb, csökkentett létszámú múszakok, maszk- vagy pajzsviselésre vonatkozó előírások, kötelező fertőtlenítés) az iparban a termelés átmeneti leállítását vagy csökkentését tette szükségessé. Nem meglepő ezért, hogy a hazai ipar húzóágazatában, a jármúiparban volt a legmagasabb azoknak az aránya (16 százalék), akiknek a koronavírus első hullámában volt olyan hetük, amikor egyáltalán nem dolgoztak (Kölló-Reizer 2021). A fizikai kontaktusokból származó kockázatok ugyanakkor alacsonyabbnak bizonyulhatnak az automatizált gyáregységekben, mint egy élő munkára nagyobb mértékben támaszkodó termelés során. A szolgáltató szektorban ezzel szemben azok a tevékenységek bizonyulhatnak kevésbé sérülékenynek, amelyek az online térbe helyezhetők, ezzel távmunkára is lehetőséget biztosítanak, vagy kiszállítással áthidalható a fizikai távolság. Egyes területeken szinte adottak voltak a távmunka feltételei (pl. informatika, tanácsadás), más 


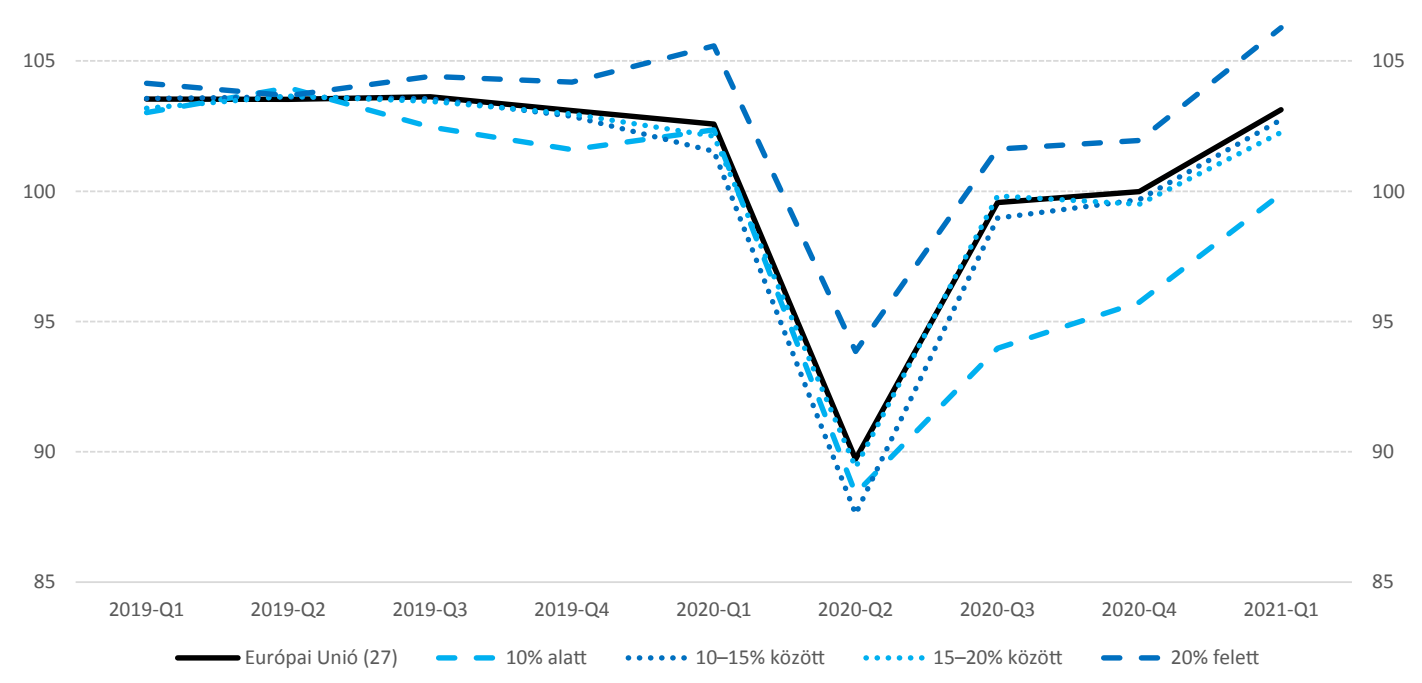

3. ábra

A GDP alakulása a hozzáadott érték ipari részesedése alapján az EU-ban (százalék, negyedév/negyedév, bázis = 2018)
Forrás: Eurostat adatok alapján saját számítás és szerkesztés

területeken jelentős erőfeszítésekbe került az átállás (pl. oktatás), máshol azonban szinte alig (pl. éttermek), vagy egyáltalán nem megvalósítható az átállás (pl. turizmus). A leállás ebből kifolyólag iparáganként eltérő következményekkel jár, amit a 2. ábra szemléltet. ${ }^{4}$

A felső ábrán jól látható a koronavírus-járvány hatása a turizmusra: míg a belföldi látogatók által eltöltött éjszakák száma a 2018. évi érték 10 százalékára, a külföldről érkezők száma gyakorlatilag nullára esett vissza. A pandémia első hullámát követő nyári fellendülés a belföldi utazásokra volt nagyobb hatással, de az újabb hullámok újfent súlyosan érintették a szektort. Amennyiben tágabb spektrumban tekintünk a szolgáltató ágazatokra (lenti ábra), úgy a magyarországi adatok is alátámasztják, hogy az olyan, távmunkában is végezhető szolgáltatások terén, mint az információ és kommunikáció, alig figyelhető meg a visszaesés, szemben más szektorokkal, ráadásul a távmunka elterjedése hosszú távú, strukturális munkaerőpiaci változásokkal is járhat. Eltérő képet mutat a kilábalás sebessége is. Jól látható, hogy az ipari termelés egy klasszikus 'V' alakú lefolyást mutat (a hirtelen visszaesést gyors talpra állás követi), míg a szállítás és raktározás, de fooképp a vendéglátás egy lassú visszarendeződést sejtető 'L' alakú görbét ír le. Utóbbi kapcsán azonban érdemes megfigyelni, hogy a belföldi turizmus sokkal gyorsabban helyreállt, 2020 nyár végére már csaknem elérte a 2018. évi szintet.

A fentiekből kifolyólag egy nemzetgazdaság külső sokkokkal szembeni sérülékenységét és talpraállási képességét nagyban meghatározhatja a gazdasági szerkezet.

\footnotetext{
${ }^{4}$ Hozzá kell tennünk, hogy az ipari termelés visszaesése közvetetten hatással van a szolgáltatásokra is, mivel az ipari munkahelyek bővülése vagy csökkenése tovagyưrüzik a szolgáltató szektorba, amivel további munkahelyek jöhetnek létre vagy szúnhetnek meg (Rueda-Cantuche el al. 2013; Sun 2017).
}

Ennek vizsgálatához csoportokba rendeztük az Európai Unió tagállamait aszerint, hogy a hozzáadott értékben mekkora a súlya a termelő szektornak. Ezt követően pedig megnéztük, hogyan változott a hazai össztermék (GDP) növekedése 2018-at követően (3. ábra).

$\mathrm{Az}$ eddig tapasztalatok alapján elmondható, hogy azokban a tagállamokban, ahol magas, 20 százalékot meghaladó a termelő szektor aránya, a járvány enyhébb visszaeséssel és gyors kilábalással járt. E tagállamok - köztük Magyarország - bizonyultak a legkevésbé sérülékenynek, és az ő esetükben beszélhetünk - az előzetes várakozásoknak megfelelően (Carlsson-Szlezak-Reeves-Swartz 2020) - a válság 'V' alakú lefolyásáról. Azonban, ahogy csökken a termelőszektor aránya, annál inkább elhúzódik a kilábalás, és egy 'L' alakú görbét rajzolva, ami lassú, több éven át tartó visszarendeződést vetít előre.

A sérülékenységre ugyanakkor a tulajdonszerkezet és a nemzetközi gazdaságba való beágyazottság is hatással van. Nem újdonság, hogy Magyarországon a külföldi tulajdonú vállalatok meghatározó szerepet töltenek be a gazdaságban: alacsony számuk (2,5 százalék) ellenére az összes foglalkoztatott 26,4 százaléka multinacionális vállalatnál dolgozott, a nettó árbevétel és a hozzáadott érték csaknem fele náluk képződött, valamint a beruházások 40 százalékát is ők hajtották végre (KSH 2020). Jelenlétük a feldolgozóiparban még dominánsabb: itt dolgozik a munkavállalók fele, és náluk realizálódik az árbevétel, a hozzáadott érték és a beruházások 70 százaléka (Vasvári-Danka-Hauck 2019). Azonban importigényük és exportfüggőségük magas, az ipari export belföldi hozzáadottérték-tartalma csak 44 százalék (Csoma 2018). A pandémia első hullámában a külföldi tulajdonú exportáló vállalatok árbevétele az átlagosnál nagyobbat zuhant, szemben a hazai tulajdonú vállalatok enyhébb visszaesésével (Köllō-Reizer 2021). Braun és Sebestyén a 
hazai jármúipar alapján végzett kutatása alapján ennek oka az lehet, hogy a külföldi tulajdonú vállalatok jobban integráltak a nemzetközi kereskedelmi hálózatokba, ezért sokkhatásoknak való kitettségük magasabb (Braun-Sebestyén 2019). Azonban e vállalatok hazai gazdaságba való alacsony beágyazottságuk ${ }^{5}$ révén csak kismértékben adják tovább ezeket a hatásokat a hazai szereplőknek. Köllő és Reizer ugyanakkor rámutat arra is, hogy a multinacionális vállalatok termelésének visszarendeződése lényegesen gyorsabb volt (lásd korábban 'V' alakú kilábalás), mint a hazai tulajdonú vállalatoknál (Kölló-Reizer 2021). Ezt a nemzetközi környezet javulása mellett magyarázhatja az is, hogy a külföldi tulajdonú vállalatok számára a vállalatcsoport jelentős előnyt tud biztosítani a menedzsment, a válságkezelés és a knowhow terén a hazai szereplőkkel szemben (VasváriDanka-Hauck 2019).

\section{A végtermékek (outputok) és azok elosztásának érintettsége}

A vállalatokat nemcsak beszállítói, de keresleti oldalról is érték sokkhatások a pandémia alatt. Bizonyos iparágakban, illetve bizonyos termékek iránt fokozott kereslet lépett fel. A tartós élelmiszerek iránt inkább rövid távon, de az egészségügyi termékek, valamint a már említett félvezetők iránt közép-, illetve hosszú távon nőtt meg a kereslet. Az igények kielégítéséhez megfelelő kapacitások kiépítésére van szükség, amely beruházásokkal, valamint a munkaerő mennyiségének növelésével járhat (EndersHaggstrom-Lalive 2020), ami azonban a helyzet fennállásának bizonytalan időtartama miatt kockázatokat is rejt magában. Más ágazatokban (ld. ruházati cikkek, üzemanyag) hosszabb időre visszaszorult a kereslet. Ez nemcsak azért problémás, mert bevételtől esnek el a vállalatok, de a vállalatoknak a készletek kezelése és raktározása további költségekkel jár, amely végső soron olyan piaci anomáliákhoz vezethet, mint a 2020 tavaszán tapasztalt negatív olajár (Mészáros 2020). Kevésbé szembetúnő következmény, de a csökkenő volumen nemcsak a jelenben növeli meg a termelési költségeket (az egy termékre jutó fix költségek emelkedésével), hanem azok a termelésból fakadó tanulási hatások sem érvényesülnek, amelyek hozzájárulhatnak a termelékenység javításához (pl. Stiglitz-Greenwald 2016; Vasvári-Danka-Hauck 2019). Sőt, a kereslet drasztikus csökkentéséből adódó termeléscsökkentés felejtéshez vezethet (pl. a munkaerő újraképzésének szükségessége miatt), amely a jövőben a termelési költségek növekedésével járhat (pl. GurtuSearcy-Jaber 2016).

A vállalatok számára jelentős kihívást jelent az output fogyasztókhoz való eljuttatása is. A szolgáltatások tekintetében már ejtettünk szót ennek meghatározó következ-

\footnotetext{
5 A hazai gazdaság dualitásáról lásd például Vasvári-Danka-Hauck (2019), Rugraff-Hansen (2011) és Lux (2017) munkáit.
}

ményeirôl, hiszen az ügyfeleknek jellemzően részt is kell venniük a termelési folyamatban. Az áruk ezzel szemben egy többlépcsős folyamaton jutnak el a vásárlókhoz. A személyes kontaktusok számának csökkentése és ennek az érdekében hozott egészségügyi rendelkezések (pl. boltzár) miatt az ellátási láncban az elosztási rendszert is újra kellett gondolni. A legkézenfekvőbb megoldásnak a disztribúció online térbe való átköltöztetése, illetve a házhozszállítási szolgáltatások bevezetése jelentette, amelyen sokszor egy-egy vállalkozás túlélése múlott. Ezért a kereskedők mellett több szolgáltató is a kiszállítás mellett döntött (pl. éttermek házhozszállítása), aminek fényében nem meglepő, hogy a csomagküldő, internetes kiskereskedelem több mint háromszorosára nőtt Magyarországon a pandémia alatt, jelentősen felülmúlva az uniós átlagot (4. ábra). A koronavírus-járvány - a távmunkához hasonlóan - strukturális változásokat indukálhat a fogyasztási szokásokban is.

A logisztikai folyamatok új kihívásairól és modern megoldásairól számos tanulmány született a járvány kitörése óta. Alicke és társai szerint a gazdasági szereplők elsősorban a keresleti előrejelzésre és az ellátó hálózat rugalmasságára koncentrálnak az ellátási láncok sérülékenységének csökkentése során (Alicke-Azcue-Barribal 2021). Jacobides és Reeves szerint pedig a nagy gazdasági visszaesések nyertesei azok a vállalatok, akik felismerik, hogy hogyan változtak meg a fogyasztói szokások, ehhez igazítják az üzleti modelljüket és a partneri hálózatukat (Jacobides-Reeves 2020). Az elosztási és a termelési funkciók fokozott együttmúködése mellett termelési oldalról a folyamatok új szempontokból történő átgondolása is szükséges lehet. A termék jellegétől függően megváltozhat a csomagolás módja, szükség lehet helyettesítő termékek biztosítására, esetleg a korábban felsorolt lehetséges problémák (pl. alkatrészhiány) miatt a termékskála szúkítésére. Bizonyos termékek esetén módosulhat a kiszerelés mennyisége. Figyelembe kell venni, hogy a kockázatkerülő fogyasztók várhatóan kevesebbszer és nagyobb mennyiségben vásárolnak. A fizetés módja az érintésmentes megoldásokra (kártyás, online fizetés, utalás) terelődhet át. E változások függvényében pedig újra kell gondolni a dolgozói létszámot, a kompetenciákat és az esetleges átképzés szükségességét. A versenyprioritási tényezők - különösen a költség, a minőség és az idő dimenzió tekintetében - akár tartósan is megváltozhatnak, illetve eltolódhat a hangsúly ezek között.

\section{Tanulságok és összegzés}

Tanulmányunkban az iparági sérülékenységet a termelés általános modelljében szereplő három fázis alapján, a beszerzés (input), a termelés/szolgáltatás (transzformáció), valamint a végtermék (output) szempontjából vizsgáltuk. E folyamatokból kiindulva, valamint statisztikai adatokra támaszkodva felvázoltuk a felmerülő fóbb problémákat, amelyekre a vállalatoknak és azok hálózatainak a lehető legrugalmasabban kell reagálniuk. 




\begin{tabular}{l|l} 
4. ábra & $\begin{array}{l}\text { A nem szakosodott bolti vegyes kiskereskedelem és a csomagküldő, internetes kiskereskedelem Magyarországon és az EU-ban (százalék, hónap/hó- } \\
\text { nap, bázis }=2018) \\
\text { Forrás: Eurostat (2019-2020) és KSH (2021) adatok alapján saját számítás és szerkesztés }\end{array}$
\end{tabular}

A beszerzés kapcsán kijelenthetjük, hogy komplex és hosszú ellátási láncokkal szemben válságállóbbnak tünnek a rövidebb értékláncok, ezzel ugyanis csökkenthetók a globális ellátási láncok komplexitásából és rugalmatlanságából eredő kockázatok. A kockázat diverzifikációját segíti eló az is, ha a vállalatok növelik a beszállítóik számát. Ennek azonban minden esetben ára van, ezért fontos, hogy a beszállítói struktúra optimalizálása során a kritikus inputoknál növeljük a rugalmasságot és az ellenálló képességet. Ez együtt járhat az értékteremtés regionalizációjával, azaz a termelési funkciók hazatelepítésével, vagy a beszállítói kör többközpontúvá tételével, ami diverzifikálhatja a termelés helyéből fakadó kockázatokat.

Rámutattunk, hogy az ellenálló képesség, a válság lefolyása több dimenzióban értelmezhető, és számos tényező befolyásolja. Láthattuk, hogy a termelő szektor válságállóbbnak bizonyult a szolgáltató ágazatoknál; ahol a termelési volumen gyorsan visszapattant, viszonylag rövid idő alatt elérve a válság előtti szinteket. Ez nemzetgazdasági szinten is érvényesül: minél meghatározóbb egy gazdaságban az ipar, az kevésbé bizonyul sérülékenynek, míg a kisebb iparral rendelkező államoknak elhúzódó kilábalással kell szembenézniük. Ugyanakkor azon szolgáltatások, amelyek online térbe áthelyezhetők és távmunkában is végezhetők, alig mutatnak visszaesést, szemben a személyes jelenlétet igénylő iparágakkal, ahol elhúzódhat a visszarendeződés.

Az outputok tekintetében elmondható, hogy az input és a transzformáció megváltozott helyzete, az új kockázatok, a keresleti sokkhatások, valamint az elosztás meg- változásának módja jelentôs hatással van a végtermékekre, szolgáltatásokra. A versenyprioritási tényezók akarva-akaratlanul megváltoznak, hiszen más lesz a költségstruktúra, jelentős bizonytalanságok állnak fenn a beszerzésben, a transzformációban, de az elosztásban is. Emiatt az idő és a flexibilitás vonatkozásában elért teljesítmény, de akár az output minősége is megváltozhat. Ezért a vállalaton belül a termelési és értékesítési funkció szoros együttmúködésére, az ellátási hálózatok szintjén a gazdasági szereplők összefogására, rugalmas alkalmazkodására van szükség az ellátás biztosítása, valamint a versenyképesség fenntartása érdekében.

Fő megállapításunk, hogy a pandémia is rámutatott arra, hogy az ipari termelés kulcsfontosságú egy nemzet gazdaságában. Mindamellett, hogy az ipari innovációk révén növekszik a termelékenység és az életszínvonal (Jacobs-Mazzucato 2018) és a gyártási funkciók jelentős multiplikátor hatással is bírnak a szolgáltató szektorra (Sun 2017), az ipar egyúttal ellenállóbbnak is bizonyul egy járvány idején. Ez pedig újabb lökést adhat az olyan fejlett gazdaságok jelenleg is futó iparfejlesztési programjainak, mint Németország, az Egyesült Államok vagy az Európai Unió (Hauck-Longaner-Vaspári 2021).

\section{Köszönetnyilvánítás}

A kutatás a TKP2020-IKA-08 számú projekt a Nemzeti Kutatási, Fejlesztési és Innovációs Alapból biztositott támogatással, a Tématerületi Kiválósági Program 2020 (2020-4.1.1-TKP2020) pályázati program finanszírozásában valósult meg. 


\section{Irodalomjegyzék}

Alicke, K., Azcue, X. \& Barribal, E. (2021) Supply-chain recovery in coronavirus times - plans for now and the future, Logisztikai Híradó, Vol. XXXI. No. 3. pp. 28-33.

Braun E. \& Sebestyén T. (2019) A magyar jármúipar beágyazottsága a hazai és nemzetközi értékesítési láncokba. Statisztikai Szemle, Vol 97. No. 7. pp. 687-720. https://doi.org/10.20311/stat2019. 7.hu0687 [Letöltve: 2021.07. 27.]

Carlsson-Szlezak, P., Reeves, M. \& Swartz, P. (2020) What Coronavirus Could Mean for the Global Economy. Harvard Business Re view, 3 March 2020

Choi, T. Y., Rogers, D. \& Vakil, B. (2020) Coronavirus Is a Wake-Up Call for Supply Chain Management, Harvard Business Review, Digital Article: https://hbr.org/2020/03/coronavirus-is-a-wakeup-call-for-supply-chain-management [Letöltve: 2021. 07. 27.]

Csatári F. D. (2021) Alkatrészhiány miatt leáll az Audi legtöbb gyáregysége. Telex, 2021. június 15. https://telex.hu/gazdasag/ 2021/06/15/alkatreszhiany-miatt-leallnak-az-audi-legtobb-gyaregysege [Letöltve: 2021. 07. 27.]

Csoma R. (2018) Beruházási támogatások, újraiparosodás és a globális értékláncok. Közgazdasági Szemle, Vol. 65. No. 3. pp. 303-324. DOI: https://doi.org/10.18414/ksz.2018.3.303 [Letöltve: 2021 07. 27.]

Dobos I. \& Vörösmarty Gy. (2020) Egy DEA modell beszállítóértékelési feladatok megoldására, SZIGMA 51 (2), 131-147.

Enders, A., Haggstrom, L. \& Lalive, R. (2020) How Reskilling Can Soften the Economic Blow of Covid-19, Harvard Business Review, Digital Article https://hbr.org/2020/06/how-reskilling-cansoften-the-economic-blow-of-covid-19 [Letöltve: 2021. 07. 27.]

Ghemawat, P. (2001) Distance Still Matters - The Hard Reality of Global Expansion. Harvard Business Review, September 2001 Issue

Gurtu, A., Searcy, C. \& Jaber, M. Y. (2016) Effects of offshore outsourcing on a nation. Sustainable Production and Consumption, Vol. 7. pp. 94-105.

Hauck Zs., Longauer D. \& Vasvári T. (2021) Termelésáthelyezési döntések modellezése a fejlett gazdaságokban, SZIGMA, Vol. 52. No. 3. pp. 269-292.

Hausmann R. (2020) A globális ellátási láncok átalakulása a feldolgozóiparban a koronavírus-járvány következtében, Hitelintézeti Szemle, Vol. 19. No. 3. pp. 130-153.

Hegedûs D. \& Vasvári T. (2020) Hazai vállalatok az értékláncban. Egy feldolgozóipari vállalat beszállítói kapcsolatainak elemzése, Közgazdasági Szemle, Vol. LXVII. No. 12. pp. 1245-1270.

Heizer, J., Render, B. M. \& Munson, C. (2017) Operations Management: Sustainability and Supply Chain Management. Pearson, 12th Global Edition

Jacobides, M.G. \& Reeves, M. (2020) Adapt Your Business to the New Reality. Harvard Business Review, September-October 2020 Issue

Jacobs, M. \& Mazzucato, M. (2018) A kapitalizmus újratervezése. In: Jacobs, M, Mazzucato, M. (szerk.): A kapitalizmus újratervezése. Kossuth Kiadó, Budapest, pp. 9-52.

Köllő J. \& Reizer B. (2021) A koronavírus-járvány első hullámának hatása a foglalkoztatásra és a vállalatok árbevételére. Közgazdasági Szemle, Vol. LXVIII. No. 4. pp. 345-374.

KSH (2020) Külföldi irányítású vállalkozások Magyarországon, 2018. https://www.ksh.hu/docs/hun/xftp/idoszaki/pdf/kulfleanyl8 pdf. [Letöltve: 2021. 07. 27.]

Lux G. (2017): A külföldi múködő tőke által vezérelt iparfejlődési modell és határai Közép-Európában. Tér és Társadalom 31. évf. 1. sz. pp. 30-52. DOI: https://doi.org/10.17649/tet.31.1.2801 [Letöltve: 2021.07.27.]
Mészáros R. T. (2020) Hogyan zuhanhatott negatívba az olaj ára? In dex.hu, 2020. május 21. https://index.hu/gazdasag/2020/04/ 21/olaj_olajpiac_negativ_ar_ingyen_benzin_osszeomlas_vilagpiaci_ar/ [Letöltve: 2021.07.27.]

Nagy V. (2021) A járvány újabb mellékhatása: nincs elég ketchup, chip, acél, múanyag és csirke. Portfolio.hu, 2021. május 16. https://www.portfolio.hu/uzlet/20210516/a-jarvany-ujabbmellekhatasa-nincs-eleg-ketchup-chip-acel-muanyag-es-csirke483350 [Letöltve: 2021.07 .27$.

Page, P. (2021) Container Shipping Prices Skyrocket as Rush to Move Goods Picks Up. The Wall Street Journal, July 5, 2021 https:// www.wsj.com/articles/container-ship-prices-skyrocket-as-rush-tomove-goods-picks-up-11625482800 [Letöltve: 2021. 07. 27.]

Reeves, M., Frste, L., Chen, C., Carlsson-Szlezak, P. \& Whitaker, K. (2020) How Chinese Companies Have Responded to Coronavirus. Harvard Business Review, 10 March 2020.

Render, B. (2021a) Auto Makers and the Global Chip Shortage, Jay, Barry \& Chuck's OM blog, https://heizerrenderom.wpcomstaging.com $/ 2021 / 02 / 18 /$ om-in-the-news-auto-makers-and-theglobal-chip-shortage/ [Letöltve: 2021.07.27.]

Render, B. (2021b) The Chip Shortage Is Far-Reaching, Jay, Barry \& Chuck's OM blog, https://heizerrenderom.wpcomstaging.com/ $2021 / 05 / 02 /$ om-in-the-news-the-chip-shortage-is-far-reaching/

Rueda-Cantuche, J. M., Sousa, N., Andreoni, V. \& Arto, I. (2013) The Single Market as an Engine for Employment through External Trade. Journal of Common Market Studies, Vol. 51. No. 5. pp. 931-947. https://doi.org/10.1111/jcms.12039. [Letöltve: 2021. 07. 27.]

Rugraff, E. - M. W. Hansen (2011): Multinational corporations and local firms in emerging economies - An introduction. In: Rugraff, E. - M. W. Hansen (szerk.): Multinational corporations and local firms in emerging economies. Amsterdam University Press, Amsterdam 2011

Sheffi, Y. (2020) Reshaping Supply Chains for Post-Pandemic World. MIT Sloan Management Review Webinar, October 2020.

Shih, W. C. (2020) Global Supply Chains in a Post-Pandemic World. Harvard Business Review. September-October 2020 Issue

Stiglitz, J. E. \& Greenwald, B. C. (2016) A tanuló társadalom megteremtése. Napvilág Kiadó, Budapest, p. 528.

Sun, I. Y. (2017) The World's Next Great Manufacturing Center. Harvard Business Review, May-June 2017 Issue

Szabad Európa (2021): SOS: veszélyben a globális ellátási útvonalak a hajókon rekedt tengerészek miatt. 2021. július 25. https://www. szabadeuropa.hu/a/sos-veszelyben-a-globalis-ellatasi-utvonalak-ahajokon-rekedt-tengereszek-miatt/31368887.html [Letöltve: 2021. 07. 27.]

Szabó B. \& Hauck Zs. (2019) Döntéstámogató módszerek a beszállító-választás optimalizálásához. SZIGMA, Vol. 50. No. 4. pp. 241261

UNCTAD (2021) Shipping during COVID-19: Why container freight rates have surged. 23 April 2021. https://unctad.org/news/shipping-during-covid-19-why-container-freight-rates-have-surged [Letöltve: 2021.07.27.]

Vasvári T., Danka S. \& Hauck Zs. (2019) Termelés és innováció - tanulságok a hazai iparpolitika számára. Közgazdasági Szemle, Vol. LXVI. No. 10. pp. 1031-1055.

de Vet, J. M., Nigohosyan, D., Ferrer, J. N., Gross, A.-K., Kuehl, S. \& Flickenschild, M. (2021) Impacts of the COVID-19 pandemic on EU industries, Publication for the committee on Industry, Research and Energy, Policy Department for Economic, Scientific and Quality of Life Policies, European Parliament, Luxembourg

Vörös J. (2018) Termelés- és szolgáltatásmenedzsment. Akadémiai Kiadó, Budapest, https://mersz.hu/kiadvany/298 [Letöltve: 2021.07.27.]

A cikk a Creative Commons Attribution 4.0 International License (https://creativecommons.org/licenses/by/4.0/) feltételei szerint publikált Open Access közlemény, melynek szellemében a cikk bármilyen médiumban szabadon felhasználható, megosztható és újraközölhető, feltéve, hogy az eredeti szerző és a közlés helye illetve a CC License linkje és az esetlegesen végrehajtott módosítások feltüntetésre kerülnek. (SID_1) 